\title{
Developing Work Motivation for Lecturers at Some Public Universities in Ho Chi Minh City, Vietnam
}

Nguyen Thi Thuy Dung, Assoc. Prof., PhD

Sai Gon University, Ho Chi Minh City, Vietnam

\begin{abstract}
This article presents the results from an investigation of current practices in building work motivation for lecturers in three public universities in Ho Chi Minh City, Vietnam. The survey aims to clarify the current state of motivational development for lecturers in these universities, and to contribute as a reference to baseline for measures to enhance the work motivations for lecturers. The survey was conducted by a combination of in-depth interview and questionnaire of 224 lecturers in the three universities. The results showed that the management of these universities have taken appropriate motivating measures, which have direct effect to the individual lecturers, through their work and through the working environment. Among them, the direct measures (raising salaray and incentives; providing supplemental pay, benefits and services; trainning and professional development) are performed the best in three universities. Howerver, the working environment enhancement measures, which require time and appropriate investment, must receive the most attention in the future.
\end{abstract}

Keywords: Work motivation, building work motivation, lecturers, Ho Chi Minh City

\section{Introduction}

The work motivation of university lecturers is one of important factors affecting their working productivity and performance; as the result, it can reflect on the training quality and the university reputation. Therefore, the university leadership needs to adopt various measures to increase their lecturers' motivation. This is one of the most important leadership functions of a university president.

In Vietnam, there is research on the management of teaching activities in universities; on the management of human resources; and on the 
professional development of management staffs and lecturers. However, there are hardly any in-depth studies on increasing the lecturers motivation.

Ho Chi Minh City is a big city and considered as a centre of economy, culture, education and trainning, techonology, and science in Vietnam. In Ho Chi Minh City there is a noticeable and intensive competition between public and private universities, domestic and forei in universities.

Therefore, it is imperative to investigate on building work motivation of lecturers in public universities in Ho Chi Minh City. The research aims to clarify the actual situation of their motivation to baseline for the practical measures to enhance work motivations among the public university teachers. This is necessary to ensure the position and the sustainable development of public universities in Ho Chi Minh City. It is necessary to approach the problem from different directions.

\section{Content}

\subsection{Literature review}

\section{Factors affecting work motivation of university lecturers}

To identify the factors affecting lecturers' motivaion, it would be necessary to review some of the better known theories of motivation $(\mathrm{Vu}$, 2009, p.240), such as:

Maslow's theory (1943) was that there are five levels of needs for humans (physiological needs $\rightarrow$ safety needs $\rightarrow$ social belonging needs $\rightarrow$ Esteem needs $\rightarrow$ self-actualization needs). When humans are satisfied their needs at lower level, the next higher needs will emerge.

Alderfer ERG theory (1969) further developed Maslow's hierarchy of needs by categorizing the hierarchy into his ERG theory: Existence $\rightarrow$ Relatedness $\rightarrow$ Growth).

Herzberg's Motivation Theory (1968)- also known as the dualfactor theory of human motivation, argues that the human work motivation comes from his job, but from the rewards or working conditions. A set of job characteristics related to survival needs (such as salary, insurance, organization policy) falls under hygiene health factors. Another set of job characteristic related to human development needs (such as activeness, recognition, responsibility, nature of work) falls under motivators. Herzberg highly appreciated the motivators, which are basic factors motivating the employees of an organization.

There are other theories of motivation. The Incentive Theory of Motivation explains employee behaviors as results of his prior rewards for his work; the Expectancy Theory (Vroom, 1964) argues that individuals can be motivated towards goals if they believe that the outcome of a favorable performance will result in their desirable rewards or in the recognition of their management. 
Based on the above theories, many authors categorise affecting factors of employee motivations. Among them are some Vietnamese authors that study on what causes school teachers and university lecturers to be motivated, such as:

In his article Woodhouse (2018) presented 26 school teacher motivation factors categorized as teacher personality, school management, school community, parents, principal capability, government education policies, civil service, curriculumn, teaching infrastructure, students, and teacher relationship with colleagues (p.311-319).

Nguyen Thi Hong Hai and Nguyen Thi Thanh Thuy (2014) presented three categories of affecting factors of school teacher motivations as personality factors, job factors and school factors (p.19-23).

Truong Duc Thao (2017) categorized into 12 motivation factors affecting to university lecturers: job awareness, satisfactions in teaching and scientific research tasks, awareness of duties and responsibilities of a teacher, self-affirmation towards one's work, student attitudes on learning and academic achievements, working conditions, job benefits, infrastructure for teaching and scientific research activities, nature of work, empowerment and responsibility in workplace, university name and social values of teachers (p.9).

Pham Thi Tan and Dang Thi Hoa (2018) presented eight lecturer motivation factors (nature of work, fairs in benefit, fairs in recognition, fairs in job promotion, fairs in relationship with colleagues, fairs of direct managers, fairs in attitude and evaluation of students, fairs in attitude and evaluation of society) (p.84-93).

From the previous research, the lecturers' work motivations are created and developed by various factors, which are divided into three groups: firstly, factors relating to individual lecturers (such as needs, incentive, interest, personal characteristics, competence,...); secondly, factors relating to their job (such as the nature of work, the importance of work,...); and thirdly, factors relating to the work environment (work conditions, leadership style, relationship with colleagues,...).

\section{Developing lecturers' work motivation}

Many authors consider the development of employee motivation as an essential aspect of leadership. According to Covey (1991), functions of leadership could be divided into two parts. One part is related to vision and mission, values and goals, while the other is related to inspiring and motivating employees to work with shared visions and goals" (p. 319). Various Vietnamese authors, such as Tran Kiem (2008), Nguyen Loc (2010), Bui Minh Hien and Nguyen $\mathrm{Vu}$ Bich Hien (2015) similarly argue that leadership involves setting goals, taking instructions and supervisions, attracting and 
motivating the employees. Therefore, creating motivation for lecturers is an essential requirement for leadership with a collection of measures to boost the lectures motivation.

From the analysis above, we can see that creating and building lecturers' motivation are influenced by various factors. Therefore, it is a basic principle of motivation that the management should adopt a collection of measurers for creating and building lecturers' motivation. These measures can be categorized into three groups: Measures affecting directly to individual lecturers (salary, incentives, payment for extra work, benefits and services); Measures through work (approriately work assignment, work authority, reasonable work evaluation,...); Measures through working environment (facilitating work environment for lecturers).

\subsection{Overview of the survey}

Survey objectives: to clarify the current state of motivational development for lecturers in some public universities in Ho Chi Minh City, and to contribute as a reference to baseline for measures to enhance the work motivations for lecturers in these universities

Survey content: evaluation of motivational measures affecting directly to lecturers, affecting their work, and working environment.

\section{Survey area and survey sample:}

The survey was conducted in three public universities in Ho Chi Minh City: Sai Gon University (SGU), HCMC University of Education (HCMUE), and Vietnam National University HCMC's University of Social Sciences and Humanities (VNUHCM-USSH).

SGU is a public university managed by People's Committee of Ho Chi Minh City. As a multi-disciplinary university, it provides undergraduate and graduate education in technology, economy, culture, social science, political science, art, and pedagogy majors. There are 20 faculties with 462 lecturers.

HCMUE is a public university managed by Ministry of Education and Training. It specializes in training of various subjects to teachers who will teach in grade schools and kindergarten. There are 22 faculties with 437 lecturers.

VNUHCM-USSH is a public university which belongs to Viet Nam National University, Ho Chi Minh City. It trained its students to be specialized in social and cultural sciences. There are 28 faculties with 983 lecturers.

The following is a survey sample of 224 lecturers in the three universities chosen by stratified random sampling method: 
Table 1. Survey sample

\begin{tabular}{|c|c|c|c|c|c|}
\hline \multicolumn{2}{|r|}{ Categories } & SGU & HCMUE & VNUHCM-USSH & Total \\
\hline \multirow[t]{2}{*}{ Position } & $\begin{array}{l}\text { Lecturer holding } \\
\text { management role }\end{array}$ & 25 & 14 & 2 & 41 \\
\hline & Non-management lecturer & 96 & 40 & 47 & 183 \\
\hline \multirow{2}{*}{ Gender } & Male & 50 & 33 & 16 & 99 \\
\hline & Female & 71 & 21 & 33 & 125 \\
\hline \multirow{3}{*}{ Age } & Under 40 & 60 & 27 & 41 & 128 \\
\hline & From $40-$ to 50 & 41 & 22 & 6 & 69 \\
\hline & Upper 50 & 20 & 5 & 2 & 27 \\
\hline \multirow{3}{*}{$\begin{array}{l}\text { Seniority in } \\
\text { teaching }\end{array}$} & Under 5 years & 23 & 5 & 24 & 52 \\
\hline & From 5 - to 10 years & 54 & 13 & 19 & 86 \\
\hline & Upper 10 years & 44 & 36 & 6 & 86 \\
\hline & Total & 121 & 54 & 49 & 224 \\
\hline
\end{tabular}

Survey methods: The survey combines the methodology of the questionnaire (quantitative method) and in-depth interviews (descriptive method).

The questionnaire is for 224 surveyed objects, which requires their evaluation on motivational measures to lecturers by a five point scale Likert.

The average point is divided into 5 levels: 1 point -1.80 points: Strongly Disagree; 1.81 points -2.60 points: Slightly Disagree; 2.61 points 3.40 points: Slightly Agree; 3.41 points -4.20 points: Moderately Agree; 4.21 points -5 points: Strongly Agree.

The methodology of in-depth interviews is conducted to clarify countable results collected from the methodology of questionnaire: in-depth interviews with 9 faculty managers ( 3 faculty managers per 1 university) and 9 lecturers (3 lecturers per 1 university):

- SGU faculty managers are coded as SG-M1 to SG-M3; HCMUE faculty managers are UE-M1 to UE-M3; VNUHCM-USSH faculty managers are SH-M1 to SH-M3.

- SGU lecturers are coded as SG-L1 to SG-L3; HCMUE lecturers are UE-L1 to UE-L3; VNUHCM-USSH lecturers are SH-L1 to SH-L3.

The content of these interviews were developed using the information from the questionnaire.

\subsection{Survey results}

\section{Motivation measures affecting directly to lecturers}

Salary and incentives

The evaluation of 224 lecturers about the motivation measures by salary and incentives in the three universities are shown in the following Table 2: 
Table 2. Evaluation of salary and incentives

\begin{tabular}{|c|c|c|c|c|c|c|c|c|c|c|c|}
\hline \multirow[b]{2}{*}{ No } & \multirow[b]{2}{*}{ Salary and incentives } & \multicolumn{2}{|c|}{ SGU } & \multicolumn{2}{|c|}{ HCMUE } & \multicolumn{2}{|c|}{ USSH } & \multicolumn{4}{|c|}{ Total } \\
\hline & & Mean & $\begin{array}{l}\text { Std. } \\
\text { dev }\end{array}$ & Mean & $\begin{array}{l}\text { Std. } \\
\text { dev }\end{array}$ & Mean & $\begin{array}{l}\text { Std. } \\
\text { dev }\end{array}$ & Mean & $\begin{array}{l}\text { Std. } \\
\text { dev }\end{array}$ & Rank & Level \\
\hline 1 & $\begin{array}{l}\text { Pay meeting requirement } \\
\text { by laws and regulations }\end{array}$ & 4.55 & 0.66 & 4.35 & 0.68 & 4.16 & 0.92 & 4.42 & 0.74 & 1 & $\begin{array}{l}\text { Strongly } \\
\text { Agree }\end{array}$ \\
\hline 2 & $\begin{array}{l}\text { Reasonable Pay } \\
\text { (work-based) }\end{array}$ & 4.31 & 0.85 & 4.06 & 1.00 & 3.71 & 1.14 & 4.12 & 0.98 & 4 & $\begin{array}{l}\text { Moderately } \\
\text { Agree }\end{array}$ \\
\hline 3 & On- time Pay & 4.39 & 0.76 & 4.41 & 0.63 & 4.24 & 0.85 & 4.36 & 0.75 & 2 & $\begin{array}{l}\text { Strongly } \\
\text { Agree }\end{array}$ \\
\hline 4 & Fair Pay (for similar jobs) & 4.29 & 0.87 & 4.17 & 0.80 & 3.92 & 1.08 & 4.18 & 0.91 & 3 & $\begin{array}{l}\text { Moderately } \\
\text { Agree }\end{array}$ \\
\hline 5 & $\begin{array}{l}\text { Incentives are compatible } \\
\text { to cost of living }\end{array}$ & 4.17 & 0.80 & 3.85 & 0.83 & 3.65 & 1.09 & 3.98 & 0.90 & 6 & $\begin{array}{l}\text { Moderately } \\
\text { Agree }\end{array}$ \\
\hline 6 & $\begin{array}{l}\text { Incentives are given } \\
\text { objectively, fairly, and } \\
\text { without discrimination }\end{array}$ & 4,21 & 0,75 & 4,02 & 0,88 & 3,90 & 0,92 & 4,09 & 0,83 & 5 & $\begin{array}{l}\text { Moderately } \\
\text { Agree }\end{array}$ \\
\hline & Total & 4,32 & 0,66 & 4,14 & 0,58 & 3,93 & 0,77 & 4,19 & 0,68 & & \\
\hline
\end{tabular}

Table 2 shows that lecturers in SGU highly evaluate its payment of salary and incentives. There are five measures which the leadership carry out well and they are evaluated at level "Strongly Agree". There is only one measure at lower level "Moderately Agree" and it is "Incentives are compatible to cost of living".

There are 2 measures performed well in HCMUE and its lecturers evaluate them at level "Strongly Agree". They are "Pay meeting requirement by laws and regulations" and "On-time pay".

During in-depth interview, opinions of lecturers being interviewed are converged. They all agree that in their universities, they all get "on- time pay" and "pay meeting requirement by laws and regulations".

There is an opinion: "The university should consider the incentives higher. It is often low and not compatible to cost of living". Howerver, this lecturer also said: "Although the incentives are not compatible to cost of living, they at least encourage them".

There is a noticable feedback: "Although young and senior lecturers having the same workload, the senior ones have higher salary because their payrate is higher" (SH-L3).

Therefore, the results of in-depth interview and questionaire are coherent. The pay of lecturers in the three universities are in accordance to regulations and delivered on time. The bonuses are encouraging lecturers but they are not high enough. Furthermore, these universities are in public sector so they must observe governmental regulations on compensation, which defines that the compensation of employees is progressive with their senority. Thus, inspite of similarity of work, young lecturers and senior lecturers have 
different payrates. The university management should explain the issue to their lecturers.

\section{Supplemental pay, benefits and services, training and professional development}

The evaluation of 224 lecturers in the three universities about supplemental pay, benefits and services, training and professional development in the last 2 years are shown in the following Table 3.

Table 3. Evaluation of supplemental pay, benefits and services, training and professional development

\begin{tabular}{|c|c|c|c|c|c|c|c|c|c|c|c|}
\hline \multirow[b]{2}{*}{ No } & \multirow{2}{*}{$\begin{array}{l}\text { Supplemental pay, benefits } \\
\text { and services, training and } \\
\text { professional development }\end{array}$} & \multicolumn{2}{|c|}{ SGU } & \multicolumn{2}{|c|}{ HCMUE } & \multicolumn{2}{|c|}{ USSH } & \multicolumn{4}{|c|}{ Total } \\
\hline & & Mean & \begin{tabular}{|l} 
Std. \\
dev
\end{tabular} & Mean & $\begin{array}{l}\text { Std. } \\
\text { dev }\end{array}$ & Mean & $\begin{array}{l}\text { Std. } \\
\text { dev } \\
\end{array}$ & Mean & $\begin{array}{l}\text { Std. } \\
\text { dev } \\
\end{array}$ & Rank & Level \\
\hline 1 & $\begin{array}{l}\text { Supplemental pay given } \\
\text { properly and adequately to } \\
\text { additional duties }\end{array}$ & 4.17 & 0.86 & 4.00 & 1.01 & 3.80 & 1.10 & 4.05 & 0.96 & 5 & $\begin{array}{l}\text { Moderately } \\
\text { Agree }\end{array}$ \\
\hline 2 & $\begin{array}{l}\text { Supplemental pay given on } \\
\text { time and openly }\end{array}$ & 4.22 & 0.82 & 4.13 & 0.67 & 4.04 & 0.87 & 4.16 & 0.80 & 3 & $\begin{array}{l}\text { Moderately } \\
\text { Agree }\end{array}$ \\
\hline 3 & $\begin{array}{l}\text { Supplemental pay given } \\
\text { equally (for similar additional } \\
\text { duties) }\end{array}$ & 4.13 & 0.88 & 4.06 & 0.90 & 3.96 & 1.00 & 4.08 & 0.91 & 4 & $\begin{array}{l}\text { Moderately } \\
\text { Agree }\end{array}$ \\
\hline 4 & $\begin{array}{l}\text { Good Insurances (social } \\
\text { insurance, medical } \\
\text { insurance,...) }\end{array}$ & 4.31 & 0.80 & 4.13 & 0.80 & 4.22 & 0.77 & 4.25 & 0.79 & 1 & $\begin{array}{l}\text { Strongly } \\
\text { Agree }\end{array}$ \\
\hline 5 & $\begin{array}{l}\text { Provide services (legal aid in } \\
\text { buying houses, cars; } \\
\text { traveling,...) }\end{array}$ & 3.97 & 0.91 & 3.65 & 1.10 & 3.31 & 1.29 & 3.75 & 1.08 & 8 & $\begin{array}{l}\text { Moderately } \\
\text { Agree }\end{array}$ \\
\hline 6 & $\begin{array}{l}\text { Flexible time arrangement of } \\
\text { professional development for } \\
\text { lecturers. }\end{array}$ & 4.26 & 0.87 & 4.24 & 0.67 & 3.84 & 1.01 & 4.17 & 0.88 & 2 & $\begin{array}{l}\text { Moderately } \\
\text { Agree }\end{array}$ \\
\hline 7 & $\begin{array}{l}\text { Adequate funding of } \\
\text { professional development for } \\
\text { lecturers. }\end{array}$ & 4.17 & 0.92 & 4.04 & 0.97 & 3.71 & 1.14 & 4.04 & 0.99 & 6 & $\begin{array}{l}\text { Moderately } \\
\text { Agree }\end{array}$ \\
\hline 8 & $\begin{array}{l}\text { Adequate rewards for } \\
\text { professional development } \\
\text { training courses }\end{array}$ & 4.09 & 0.89 & 3.93 & 1.06 & 3.78 & 1.07 & 3.98 & 0.98 & 7 & $\begin{array}{l}\text { Moderately } \\
\text { Agree }\end{array}$ \\
\hline & Total & 4.17 & 0.75 & 4.02 & 0.70 & 3.83 & 0.80 & 4.06 & 0.76 & & \\
\hline
\end{tabular}

Table 3 shows that there are 3 measures implemented primarily in SGU and they are evaluated at level "Strongly Agree" ("Supplemental pay given on time and openly", "Good insurances (social insurance, medical insurance)", "Flexible time arrangement of professional development for lecturers"). The remaining 5 measures are at level "Moderately Agree". The evaluation is converged (all standard deviations are lower than 1).

In HCMUE, there are 8/8 measures evaluated at level "Moderately Agree". 
In VNUHCM-USSH, there is only 1 measure evaluated at level "Strongly Agree" ("Good insurances (social insurance, medical insurance)”) and 1 measure at level "Slightly Agree" ("Provide services such as legal aid in buying houses, cars; traveling,...”). The remaining 6 measures are at level "Moderately Agree".

Information collected from the in-depth interview illustrated the above results. There is a convergence of opinions of $100 \%$ interviewed lecturers in the 3 universities:

"The university is providing good social benefits for the lecturers such as the social insurance and the medical insurance".

"Lectures who have a permission of the university director to participate in doctoral training programs are exempt from teaching hours and scientific research activities".

"Teacher compensation and supplemental pay which are set by Government Laws and Regulations are properly and primarily implemented".

There are also negative opinions during in-depth interview as following:

"The university provides financial support during professional development programmes but payment procedures are quite complicated and time consuming" (SG-L3);

"The role of teaching assistants is more stressfull than research assistants. Teaching assistants work hard during the whole school year and it is relevant to the teaching and learning of lecturers and students, while research assistant job is temporary and nonstressful. Nevertheless, their compensation are paid equally which is not reasonable"(SG-L1 và SG-L2).

"Many lecturers expect support from their universities for service aid in buying houses, cars, traveling,... but the management do not proactively support on those. These service aids are not provided adequately at the universities". (SH-L1, SH-L2).

Thus, the survey results showed that the management of the 3 universities make an effort to enforce properly and openly the payrate, incentives and supplemental pay. Howerver, they should explain and encourage their lecturers to share these issues to establish a better understanding among lectures and the university on the common difficutlies that the university is facing. Beside that, they should find ways to come up with various rewards and incentives and to implement better services support the lecturers.

\section{Motivation measures affecting through work}

The evaluation of 224 lecturers about motivational measures through work implemented by their university management in the last 2 years are shown in the following Table 4. 
Table 4. Evaluation of motivational measures through work

\begin{tabular}{|c|c|c|c|c|c|c|c|c|c|c|c|}
\hline \multirow{2}{*}{ No } & \multirow{2}{*}{$\begin{array}{c}\text { Motivational measures } \\
\text { through work }\end{array}$} & \multicolumn{2}{|c|}{ SGU } & \multicolumn{2}{|c|}{ HCMUE } & \multicolumn{2}{|c|}{ USSH } & \multicolumn{4}{|c|}{ Total } \\
\hline & & Mean & std. de & Mean & tdd de & Mean & td. de & Mean & td. de & Rank & Level \\
\hline 1 & $\begin{array}{l}\text { Lecturers are assigned work } \\
\text { appropriately to their } \\
\text { qualifications and } \\
\text { competencies }\end{array}$ & 4.25 & 0.73 & 4.22 & 0.77 & 3.92 & 0.81 & 4.17 & 0.77 & 1 & $\begin{array}{l}\text { Moderately } \\
\text { Agree }\end{array}$ \\
\hline 2 & $\begin{array}{l}\text { Lecturers are assigned work in } \\
\text { consideration of their needs } \\
\text { and circumstances }\end{array}$ & 4.08 & 0.81 & 3.96 & 0.82 & 3.76 & 1.01 & 3.98 & 0.87 & 3 & $\begin{array}{l}\text { Moderately } \\
\text { Agree }\end{array}$ \\
\hline 3 & $\begin{array}{l}\text { Universities primarily increase } \\
\text { lecturers' awareness of the } \\
\text { importance of teaching. }\end{array}$ & 4.01 & 0.81 & 3.81 & 0.75 & 3.80 & 0.87 & 3.92 & 0.81 & 6 & $\begin{array}{l}\text { Moderately } \\
\text { Agree }\end{array}$ \\
\hline 4 & $\begin{array}{l}\text { University primarily increases } \\
\text { lecturers' awareness of the } \\
\text { importance of scientific } \\
\text { research. }\end{array}$ & 3.93 & 0.89 & 3.76 & 0.73 & 3.78 & 0.94 & 3.86 & 0.87 & 8 & $\begin{array}{l}\text { Moderately } \\
\text { Agree }\end{array}$ \\
\hline 5 & $\begin{array}{l}\text { Lecturers are encouraged to be } \\
\text { proactive at work }\end{array}$ & 4.02 & 0.76 & 4.04 & 0.80 & 3.92 & 0.86 & 4.00 & 0.79 & 2 & $\begin{array}{l}\text { Moderately } \\
\text { Agree }\end{array}$ \\
\hline 6 & $\begin{array}{l}\text { Lecturers are engaged in } \\
\text { general management activities }\end{array}$ & 3.85 & 0.86 & 3.83 & 0.80 & 3.78 & 0.98 & 3.83 & 0.87 & 9 & $\begin{array}{l}\text { Moderately } \\
\text { Agree }\end{array}$ \\
\hline 7 & $\begin{array}{l}\text { University has criteria for job } \\
\text { evaluation which are clear, } \\
\text { specific and quantifiable }\end{array}$ & 3.96 & 0.90 & 3.93 & 1.03 & 3.88 & 0.88 & 3.93 & 0.92 & 5 & $\begin{array}{l}\text { Moderately } \\
\text { Agree }\end{array}$ \\
\hline 8 & $\begin{array}{l}\text { University has processes for } \\
\text { job evaluation which are } \\
\text { reasonable and with lecturer's } \\
\text { participation }\end{array}$ & 3.96 & 0.87 & 3.87 & 0.97 & 3.83 & 0.97 & 3.91 & 0.92 & 7 & $\begin{array}{l}\text { Moderately } \\
\text { Agree }\end{array}$ \\
\hline 9 & $\begin{array}{l}\text { Evaluation results are used in } \\
\text { decision on salary, incentives } \\
\text { and promotion }\end{array}$ & 4,02 & 0,86 & 3,81 & 0,95 & 3,86 & 1,08 & 3,94 & 0,94 & 4 & $\begin{array}{l}\text { Moderately } \\
\text { Agree }\end{array}$ \\
\hline & Total & 4.01 & 0.72 & 3.92 & 0.68 & 3.83 & 0.81 & 3.95 & 0.73 & & \\
\hline
\end{tabular}

Table 4 shows that the evaluations of 224 lecturers are mostly consistent in all motivational measures through work. For the survey sample, the standard deviations are lower than 1, and it's convergence is high and the dispersion is low.

The analysis show that:

- Lecturers in SGU and HCMUE evaluated 9 measures affecting through work which are implemented in their universities as follow: There is only one measure at level "Strongly Agree" and it is "Lecturers are assigned work appropriately to their qualifications and competencies". The remainning 8 measures are at level "Moderately Agree".

- Lecturers in VNUHCM-USSH evaluated all 9 measures at level "Moderately Agree".

The in-depth interview also obtained some noticable opinions: 
$100 \%$ interviewed lecturers in the 3 universities highly evaluated the measure of assigning work appropriately to qualifications and competencies of lecturers.

Howerver, $100 \%$ interviewed lecturers in the 3 universities gave an opinion in common and it is "The criteria for job evaluation are non-specific and non-quantifiable".

Thus, the investigation usess questionnaire and in-depth interview clarify that lecturers in the three universities evaluate the motivational measures affecting through work implemented moderately.

\section{Motivation measures affecting through working environment}

The evaluation of 224 lecturers about motivation measures through working environment are shown in the following Table 5.

Table 5. Evaluation of motivation measures through work

\begin{tabular}{|c|c|c|c|c|c|c|c|c|c|c|c|}
\hline \multirow[b]{2}{*}{ No } & \multirow[b]{2}{*}{$\begin{array}{l}\text { Motivation measures through } \\
\text { working environment }\end{array}$} & \multicolumn{2}{|c|}{ SGU } & \multicolumn{2}{|c|}{ HCMUE } & \multicolumn{2}{|c|}{ USSH } & \multicolumn{4}{|c|}{ Total } \\
\hline & & Mean & $\begin{array}{l}\text { Std. } \\
\text { dev }\end{array}$ & Mean & $\begin{array}{l}\text { Std. } \\
\text { dev }\end{array}$ & Mean & $\begin{array}{l}\text { Std. } \\
\text { dev }\end{array}$ & Mean & $\begin{array}{l}\text { Std. } \\
\text { dev }\end{array}$ & Rank & Level \\
\hline 1 & $\begin{array}{l}\text { Lecture halls, learning rooms, } \\
\text { working rooms are safe, clean and } \\
\text { bright }\end{array}$ & 3.79 & 1.00 & 3.91 & 1.01 & 3.71 & 1.00 & 3.80 & 1.00 & 4 & $\begin{array}{l}\text { Moderately } \\
\text { Agree }\end{array}$ \\
\hline 2 & $\begin{array}{l}\text { Equipment and facilities for teaching } \\
\text { and research are well equipped. }\end{array}$ & 3.74 & 1.01 & 3.74 & 1.08 & 3.61 & 1.11 & 3.71 & 1.05 & 5 & $\begin{array}{l}\text { Moderately } \\
\text { Agree }\end{array}$ \\
\hline 3 & The leadership style & 4.07 & 0.81 & 4.33 & 0.67 & 4.04 & 0.82 & 4.13 & 0.78 & 1 & $\begin{array}{l}\text { Moderately } \\
\text { Agree }\end{array}$ \\
\hline 4 & Developing c & 4.02 & 0.82 & 4.09 & 0.76 & 4.00 & 0.87 & 4.04 & 0.81 & 2 & $\begin{array}{l}\text { Moderately } \\
\text { Agree }\end{array}$ \\
\hline 5 & $\begin{array}{l}\text { Well organizing emulatic } \\
\text { movements, group activi }\end{array}$ & 3.97 & 0.77 & 3.85 & 0.81 & 3.90 & 0.92 & 3.92 & 0.81 & 3 & $\begin{array}{l}\text { Moderately } \\
\text { Agree }\end{array}$ \\
\hline & Total & 3.92 & 0.76 & 3.99 & 0.68 & 3.85 & 0.82 & 3.92 & 0.76 & & \\
\hline
\end{tabular}

Table 5 showed that:

- Lecturers in SGU and VNUHCM-USSH give their opinion "Moderately Agree" to all 5/5 motivation measures through working environment

- Lecturers in HCMUE evaluated at level "Strongly Agree" for only one issue "The leadership style is democratic" (4,33 points). The remainning 4 measures are at level "Moderately Agree".

The total synthesis of 3 universities shows that all measures affecting through working environment are at level "Moderately Agree"; among them are 3 measures at lower ranking and they are "Equipment and facilities for teaching and research are well equipped" (rank 5); "Lecture halls, learning rooms, working rooms are safe, clean and bright" (rank 4) and "Well organizing emulation movements, group activities..." (rank 3).

The in-depth interview shows that although the managment invested 
on infrastructure and equipments for teaching activities, there are still shortages because of financial difficulties.

Some noticable opinions from the interviews:

"Despite objective reasons for aging facilities, the management should supervise a janitor team and the team should enhance their attitude and professional skills" (SG-L1, SG-L2).

"Some lecturers and students have less awareness of protection of public property. The managment should improve awareness of lecturers and students on the importance of preservation of equipments and facilities, as well as continously supervise their behaviour to last the lifespan of equipments" (SH-L1, SH-13).

The in-depth interview give results consistent with questionnaire.

Table 6 summarise the total results of the survey on motivational measures in 3 universities.

Table 6. Synthensis of groups of motivation measures in three universities

\begin{tabular}{|c|l|c|c|c|c|c|}
\hline TT & \multicolumn{1}{|c|}{ Group of motivation measures } & SGU & HCMUE & USSH & \multicolumn{2}{|c|}{ Total } \\
\cline { 3 - 7 } & Mean & Mean & Mean & Mean & Rank \\
\hline 1 & $\begin{array}{l}\text { Measures through salary and } \\
\text { incentives }\end{array}$ & 4.32 & 4.14 & 3.93 & 4.19 & 1 \\
\hline 2 & $\begin{array}{l}\text { Measures through supplemental pay, } \\
\text { benefits and services, training and } \\
\text { professional development }\end{array}$ & 4.17 & 4.02 & 3.83 & 4.06 & 2 \\
\hline 3 & Measures affecting through work & 4.01 & 3.92 & 3.83 & 3.95 & 3 \\
\hline 4 & $\begin{array}{l}\text { Measures affecting through working } \\
\text { environment }\end{array}$ & 3.92 & 3.99 & 3.85 & 3.92 & 4 \\
\hline
\end{tabular}

Table 6 shows that measures affecting directly to lecturers (salary and incentives, supplemental pay, benefits and services, training and professional development) are implemented primarily in 3 universities. The measures affecting through working environment should be focused in the next time. It requires time and suitable investment to progress.

\section{Conclusion}

The theoretical research shows that developing lecturers' motivation is one of important leadership functions, which is a system of measures implemented by the management to motivate their lecturers. These motivational measures could be divided into three groups: Measures affecting directly to lecturers (salary and incentives, supplemental pay, benefits and services); Measures affecting through work (approriately work assignment, work authority, reasonable work evaluation); Measures affecting through working environment (facilitating working environment for lecturers). 
The practical research was conducted by a combination of in-depth interview and questionnaire of 224 lecturers in three public universities in Ho Chi Minh City. The result showed that the management of these universities have taken appropriate measures to motivate their lecturers with three groups of 28 specific measures.

The management of the three universities executed measures affecting directly to lectures, measures affecting through work and measures affecting through working environment. Among them, measures through salary and incentives are primarily implemented. In the future, the other measures should be considered and implemented better appropriate to practical conditions of each universities.

\section{References:}

1. Bui, M. H., \& Nguyen, V. B. H. (2015). Management and Leadership of university. University of Education Publishing House.

2. Covey, S. R. (2018). Principle - Centered Leadership. (Translator: Nguyen, T. V.). Ho Chi Minh City General Publishing House.

3. Nguyen, L. (2010). Management theories. Hanoi University of Education Publishing House.

4. Nguyen., T. H. H., \& Nguyen, T. T. T. (2014). Motivation and the development of motivation for upper secondary school teachers and staff. The second upper secondary education development project, Ministry of education and training Vietnam.

5. Nguyen, T. P. L. (2015). Improving the motivation toolkit for staff in public-sector organizations. $\mathrm{PhD}$ Thesis of administration in the public sector, National Academy of Public Administration.

6. Pham, T. T., \& Dang, T. H. (2018). Factors affecting to the motivation of lecturers in the Vietnam National University of Forestry. Journal of Forestry Science and Technology, 3, 84-93.

7. Tran, K. (2014). The Scientific Basis of Education Management. (6th edition). Ha Noi University of Education Publishing House.

8. Truong, D. T. (2017). Work motivation of lecturers in private universities in Vietnam. PhD Thesis of Economics, VNU University of Economics and Business.

9. Vu, D. (2009). The psychology of management. Coursebook. Hanoi University of Education Publishing House.

10. Woodhouse, S. J. (2018). International lessons learnt on teacher motivation. In Proceeding of International Scientific Conference, The quality of teachers and education managers in the current context: The trend in Vietnam and the world (pp.311-319). National Economics University Publishing House. 